\title{
The City Is Not Innocent: Homelessness and the Value of Urban Parks
}

\section{Authors:}

Jessie Speer, School of Geography, Queen Mary University of London

Eric Goldfischer, Department of Geography, Environment, and Society, University of Minnesota

\begin{abstract}
This paper builds on contemporary memoirs of homelessness from cities across the United States to develop a more nuanced understanding of the use value of urban parks and green spaces. Based on analysis of more than seventy memoirs, we synthesize the writings of nine memoirists who examine their relationship to green spaces in cities. Instead of framing nature as something pristine and distinct from society - or something dangerous and untamedthese writings portray urban green spaces as sites of belonging and everyday life. In the US today, cities often value parks either as playgrounds for middle-class leisure or devalue them as targets of racialized anti-homeless policing. In both instances, parks are framed in relation to their impact on the exchange value of surrounding urban areas. In contrast, the memoirs of homelessness we examine portray parks and other green spaces as enabling privacy, survival, and emotional solace in an urban landscape often marked by surveillance, deprivation, and violence. These crucial values reveal a new conceptualization of urban parks as profoundly useful to those who are subject to the exclusions of capitalist property.
\end{abstract}

Keywords: Homelessness, value, urban ecology, parks, memoirs, nature 


\section{The City Is Not Innocent: Homelessness and the Value of Urban Parks}

The city of Los Angeles sat off in the distance sparkling as if that made it innocent. Funny how being way up here in the middle of nature makes the city below look like nature too.

\section{_-David Walter Smith, In a Van Down by the Ocean: A Homeless Memoir}

In his self-published Homeless Memoir, David Walter Smith captures the paradoxical relationship between urban space and the natural world. From the vantage point of the mountainous park where he lived, Smith writes the city began to look like a feature of the natural landscape. At the same time, he suggests that the city was not "innocent," recalling the constant surveillance he experienced as a result of his homelessness. In this dual space of Los Angeles, park spaces were crucial to Smith's survival. The American imaginary has long assigned value to parks as a site of temporary escape from the fast-paced world of city life. Yet parks are also central to the everyday livelihoods of those who are displaced from capitalist housing markets and driven out of other city spaces. Building on the writings of homeless memoirists, in this paper we ask: what theories of the value of urban parks arise when we take the perspective of those without property?

We argue that memoirs of homelessness highlight a range of largely unrecognized values of green spaces in cities, and that these values directly oppose those often articulated by the state and private capital. For people without property, urban green spaces can provide privacy, survival, and solace in the face of extreme surveillance, deprivation and violence. In contrast, city governments often value urban parks as sites of leisure, consumption, and increased property values in surrounding areas. In addition to officially designated parks, we examine undeveloped 
green spaces adjacent to large urban infrastructure projects, waterways, abandoned lots, and other interstitial urban spaces. By and large, memoirs of homelessness represent such spaces as essential to everyday material and spiritual sustenance, particularly as refuges from the racialized overpolicing that began to define the experience of homelessness in US cities in the late 1980s. In the section that follows, we examine how valuations of nature intersect with the politics of homelessness, before elaborating on the analytical contributions of memoirists.

\section{Homelessness and the value of nature}

Geographers have long acknowledged that nature and society are fundamentally interrelated. At the same time, the production of nature is uneven, as both human and nonhuman factors have varying degrees of influence across a range of spaces (Smith 1984; Gandy 2002). While urban green spaces are less produced than built environments constructed from concrete and asphalt, they are nonetheless developed and regulated in ways that shed light on a particular set of values the city attributes to nature. Late 19th and early 20th century urban planners often valued city parks as sites of peaceful respite within the harsh and fast-paced world of city life (Eisenman 2016). Influential landscape architects such as Frederick Law Olmstead in New York and Baron Hausmann in Paris designed parks to be central to bourgeois public life, places for the refined contemplation of nature, as well as sport, leisure, and play (Jacobs 1961). In this this view, urban parks were a means to redeem the dirty, noisy, and stressful reality of urban life. Nature in the city became something to be produced for the sake of tranquility and escape from everyday life under urban capitalism. In the years following World War II, as single family housing in suburban areas became the dominant form of state-supported housing, the sociality of nature shifted towards the privatized green space of the back yard (Jackson 1985). Such spaces became integral to the American cult of domesticity, as suburbia represented escape from the 
crowded and racialized urban core. Elites paid more for land located adjacent to green spaces and developed privately owned and heavily manicured lawns and gardens. Today, lawns collectively comprise one of the largest landscapes in the US (Robbins 2012). Throughout this process, nature became something to be purchased and cultivated by middle and upper income communities to escape the specter of urban life (Erickson 2011; Simon and Algona 2013).

At the same time, the state has historically devalued the use of nature for anything other than play or recreation. Outside of cities, national parks—as sites of "pristine" wilderness for bourgeoisie pleasure — have historically punished poor and indigenous groups who use the land as a source of sustenance and survival (Kosek 2006). Lisa Goff (2016) argues that while middleclass homesteading was historically revered as rugged survivalism, poor people's homesteading practices were condemned. Similarly, while recreational camping is celebrated today among the middle-classes as a return to nature (Moore et al. 2003), homeless people's survival camping is deemed illegal and unsanitary (Speer 2016; 2017). Spaces assigned to the natural sphere are also persistently racialized both alongside and against the built environment. Finney (2014) argues that the construction of nature as a white space obscures the history of racist policy that denied certain groups access to natural resources. Homeless people, consistently pushed out of urban park spaces, constitute one such group (Mitchell 2003). As people of color disproportionately experience homelessness in the US and access to property has been profoundly bound up with whiteness (Willse 2015), such anti-homeless responses are best understood as racialized in ways that influence how park spaces are imagined, produced, and policed.

Just as wilderness planning excluded rural communities who use the land for sustenance, cities refuse to tolerate the use of public parks for survival and everyday life. A survey of national print news media over the past two decades reveals that homelessness is often policed 
by parks departments rather than municipal police, indicating that homelessness is framed as a violation of park rules and regulations (see Downey 1995; Brovsky 2001; Mollins 2004; Tuft 2009; Kim 2011; Emmons 2013; 2015). At the same time, the policing of park spaces is far from uniform. Where once cities lavished attention on iconic large parks, these spaces now only receive a small portion of funding, as compared to newer greening projects such as linear design parks and revitalization projects along waterfronts (Larson 2013). With the labor of enforcement increasingly coming from welfare recipients in mandatory work programs, less time and attention is spent on removing homeless people from older, poorly funded parks (Krinsky and Simonet 2017). Often, architecture is left to serve this function, as with park benches designed to prevent sleeping or lying. Policing and governance both demonstrate the movement of value between different kinds of urban green spaces, and the shifting relationship of homelessness to both.

The dualistic valuation and devaluation of urban parks - as sites of pleasure, and sites of danger - reflects a larger duality built into the American imaginary that dates back to Hobbesian and Darwinian understandings of a brutal and competitive nature, against which humans must construct civilization as a means to insulate and protect themselves. Environmental theorists critiqued such understandings, framing nature instead as pristine or sacred, rather than untamed and terrifying (Tuan 1972), and later challenging dualistic approaches to environmental thinking (Cronon 1996). Beyond the valuation and devaluation of nature as an object, neoliberal cities in the US today increasingly value all urban spaces as vessels for profit-making (Theodore, Peck, and Brenner 2011). Henri Lefebvre (1991) argued that the broader process of capitalist urbanization itself transforms space into a series of commodities assigned units of equivalence to ensure their exchangeability on the market, as reflected in the prices of urban infrastructures, 
buildings, and land. Thus, the use values of a diverse range of spaces - including parks and wilderness areas - are often subsumed by the logics of exchange.

Urban political ecologists have recently turned their attention to the impact of increases in the value of urban green space, arguing that the valuation of such spaces is itself defined by uneven access - both to these environments themselves, and to the benefits produced from their transformation (Kenney-Lazar and Kay 2017; Huber 2018). The process of valuation thus primarily functions to further exacerbate patterns of uneven development, extending geographies of inequity across green landscapes (Goodling et al. 2015). In their work situating the role of value in urban political ecology, Swyngedouw and Heynen (2003) specifically note that "metabolized socionatures"- a term for understanding the processes that result from the mixture of human labor with nonhuman landscape features—-become a vehicle for extrapolating exchange value from use value in capitalist development. This plays out in processes of green gentrification, where the logics of environmental sustainability become a justification for displacement through sharp increases in land value that do not actually produce the environmental benefits used to justify them (Rice et al 2019; Curran and Hamilton 2013; Checker 2011, Anguelovski et al 2018).

Today, the value of nature is often understood through studies of ecosystem services, a framework that simultaneously measures value in both its exchange form (Costanza et al 1997) and the environmental and psychological benefits such spaces provide (Kumar and Kumar 2008). Arguing that ecological elements such as rivers, lakes, mountains, valleys, and shorelines are natural capital, ecosystem services literature argues that protecting such resources against overuse and abuse by humans is itself productive of capitalist value (Costanza et al 1997, Brown et al 2007, England 2000). But the orientation of value in ecosystems - even when framed in 
terms of use value — concerns the housed "public," and has yet to explore the perspective of homelessness, even as the relationship between homeless city dwellers and urban green spaces often lies at the heart of contestations over such areas (Dooling 2009). While urban green spaces are valued primarily based on their desirability as sites of middle class leisure, they also represent bastions of protected public space within an increasingly privatized urban landscape (Wilson 1991; Mitchell 1997; Larson 2013). These conflicting valuations have even higher stakes now as cities have increasingly turned to green infrastructure- the creation of green public spaces, revitalized waterfronts, and horticultural installations - as a primary driver of economic growth, eschewing a previous emphasis on attracting employers to redesigned business and entertainment districts (Quastel 2009; Safransky 2014; Doshi 2018).

As we argue in the sections below, memoirs of homelessness outline an alternative understanding of the value of parks and other green spaces not as objects to be manipulated, but as a relationship based in intimate everyday practices of belonging. By highlighting a crucial use value of urban parks - as essential to survival itself — such memoirs challenge how capitalist exchange comes to dominate the valuation of city spaces. While much attention has been paid to how homelessness policy shapes the urban built environment (Kerr 2011), laws that regulate and limit the use of public space (Mitchell 2003; Vitale 2008; Beckett and Herbert 2009), and the growth of a nonprofit response system (Gowan 2010; Stuart 2016), very little work has taken up the relationship between the creation of value, homelessness, and parks as a key feature of urban space. Here, we propose to remedy this, specifically from the epistemic position of experts on the experience of homelessness: homeless and formerly homeless writers. We do so by interpreting a set of writings rarely put at the center of academic scholarship. 


\section{A word on sources}

Over the last several decades, free self-publishing platforms have enabled an explosion in the production of memoirs of homelessness, many of them written by authors who were living on the streets or in shelters at the time of writing. Using multiple library and bookseller databases, we compiled an annotated bibliography of 215 memoirs of homelessness, excluding authors who did not explicitly self-identify as homeless or who adopted homelessness as a purposeful experiment. We limited our analysis to texts published since 1980, as this time period reflects a historically specific geography of homelessness in American cities, marked both by hyperpolicing and the increased use of green development as a tool for revitalization. To engage a close reading of the texts, we limited our analysis to a subset of 74 narratives. In selecting this sample, we sought to remedy the unequal representation in the overall collection. Although roughly a third of the texts were authored by women and writers of color, around half of our selected texts were by women writers, as well as authors of color. We also analyzed an equal number of texts published by established presses as self-published texts. Finally, although nearly half of the memoirs were set in eight large megacities, we included as wide a range of cities as possible to get a better sense of the diversity of urban experiences.

In analyzing memoirs, we do not make claims to empirical truths about homeless people's use of urban green spaces. The memoirists we cite cannot be read as representing the general experience of homelessness, as most people without housing do not have the resources to write, let alone publish, their stories. Instead, we read homeless authors as social critics whose vantage point offers a unique perspective on city spaces (see Speer 2019a). Some of our sources, such as the writings of the artist David Wojnarowicz, are fairly well known and have been the subject of analysis before; others are discussed academically for the first time in this paper. Such 
life narratives enable us to move beyond treating homeless voices as secondary and empirical, and to instead examine how homeless authors write about their own experiences. Based on our analysis, we identified nine texts in which the authors describe in-depth their relationship to urban parks and green spaces. While the texts disproportionately represent a masculine and white perspective, they also reflect women and minorities' experiences of homelessness as well as accounts of discrimination in connection to race, gender, sexuality and disability. What all authors share in common is the experience of being unable to pay for housing, and creating homes in urban greenspaces.

\section{The use values of urban parks: privacy, survival, and solace}

Memoirs of homelessness suggest that parks are a profoundly valuable resource for those without property: as sites for homemaking and privacy, survival in an increasingly commodified urban landscape, and emotional solace against the violence of policing and domesticity. In each of these moments, urban green spaces — and nature more broadly—represent for homeless memoirists a source of sustenance and solace amidst the brutality of American urbanism. In his memoir Travels with Lizbeth, Lars Eighner writes about the experience of camping outside in cities across the US southwest during the 1980s, alongside his dog Lizbeth. He describes how he was able to create an encampment in a remote park in Austin, Texas using salvaged materials:

I installed cushions and a foam mattress on them. I put in makeshift bookshelves. I found some large fresh dry cells and wired them to a radio so I did not have to change the batteries every hour as I listened to the news. When I satisfied myself that the light in my camp would not call attention to us at night, I discovered how to make lamps that would burn on cooking oil, a commodity that was always available in abundance in the Dumpsters. ... I set out vessels to catch rainwater.... Why shouldn't I try to make us as comfortable as I could, wherever I could? $(2013,263)$.

In using the language of comfort, Eighner emphasizes that the "bamboo" offered a reprieve from the experience of living in highly-visible urban spaces, subject to constant surveillance. 
Douglas Townsend, who lived for ten years in a tent on the outskirts of Houston, selfpublished an e-book about his homelessness in 2011. He writes, "Since I loved camping and have stayed in the woods for weeks at a time for recreation, then why not do it for real? So, I found a wooded spot and made a home" (2011, chapter 1). In describing his camping as "real" rather than recreational, Townsend calls attention to the stark contrast between middle-class uses of peri-urban natural spaces and his own. He describes making his campsite as homelike as possible:

I had built two fire pits from rock and stones, one for cooking and one for heat and burning trash. I had a tent complete with a twin bed and a smaller tent which I kept my clothes in. A patio set inside the tent that I dined upon. "Lean-to's" built around it to shield the wind in winter. Two lanterns placed along the obscure path that led to the site, and two at the site. A gas stove, and battery operated T.V. All the conveniences of home such as it were. It had become a home, my home. (2011, chapter 5)

Townsend was able to create his makeshift home because of the relative privacy afforded by dense woodland.

Brooke Willett also lived in both urban and rural parks over a period of eight years after she was evicted from her home in southern California in 2007. In her self-published digital memoir How To Be a Hobo, she describes the natural world as her home, placing it at the center of everyday life and spatial belonging:

Home is in the forest or any gathering of trees. Mother Nature provides a space for anyone and everyone to reside, and she does not discriminate nor charge any hidden fees. There is no fine print. All are welcome, and all are at home in nature. This is where we come from, and this is where we can always go back. (2015, chapter 1)

In describing nature as a metaphysical home, Willett also reveals how a "gathering of trees" makes it possible for a person without property to claim a right to space. In describing nature as unattached to "hidden fees," she indicates that parks can provide a dwelling space not tied to commodity relations. 
Yet not all urban green spaces are equally free from the public gaze. Eighner writes about finding "comfort" in his remote encampment, "Of course this was a policy easier to effect while we were out of public view in the bamboo, than it would have been if we were still sleeping in the open in Adams Park" (2013, 263). In distinguishing between Adams Park—an open and public park area-from more remote urban green spaces, Eighner suggests that survival in the city is far easier in hidden urban wilderness areas than developed parks. Willett similarly writes about seeking out wooded areas on the outskirts of towns, "When sleeping in the forest, there's less chance of getting caught by law enforcement. Tents may protect you, or they could be an invitation for trouble, so use your best judgment. People don't always appreciate tents in town" (Willett 2015, chapter 2). Cadillac Man, in his memoir Land of the Lost Souls, describes his experiences of living outside in New York City during the 1990s and 2000s. He accounts for a range of different spaces in the city where he found refuge:

Central Park is ideal because it's so big, and the precinct over there doesn't have enough man-power to cover the whole area. And the Parks Department doesn't have that many people. ... The bigger the park, the better. Astoria Park is no good. It's not that big, and they patrol it. $(2009,244)$

For those without property, the value of urban parks reflects the degree to which such spaces are shielded from urban governance and property restrictions. In all of these passages, the writers call attention to the visuality of anti-homelessness and the importance of finding privacy (Sparks 2010; Goldfischer 2018; Speer 2019b).

Although urban parks often provide much-needed privacy, many writers described how park officials themselves increasingly take on the role of policing. Richard LeMieux (2009), who became homeless in Bremerton, Washington, describes how park rangers often evicted people from the state parks adjacent to the city. He writes, "I should have known that the homeless would not be welcome at the state park. ... Money was welcome, but not people.... The 
Washington State Parks had been turned into profit centers" $(2009,306)$. Willett (2015, chapter 4) similarly critiques the US Forest Service for "privatizing, running and over-regulating public property, namely national forests." Smith describes being cited by park rangers on the beachfront areas of Santa Monica, where rangers are tasked with policing homelessness (Public Service Officers 2018). He describes such rangers as "officers in beige and green," calling attention to the blurred line between park official and police officers (2011, chapter 27). He writes, "No one wanted us there, us being the van dwellers and the homeless, so it behooved us to blend into the woodwork whenever possible" (2011, chapter 6). As cities increasingly develop new hybrid forms of governance that combine park management with anti-homeless policing, the crucial use values of urban green spaces are under threat. This trend sheds light on the importance of valuing parks not only for middle-class leisure, but as sites where people can establish a modicum of privacy and freedom from surveillance.

Many memoirists also compared their experiences living in park spaces to a form of wilderness survival. As Eighner writes, "The land is now covered with cities. The cities are full of Dumpsters. ... When we go around to the Dumpsters, we are hunting. I think of scavenging as a modern form of self-reliance" $(2013,131)$. Unlike recreational campers, Eighner did not procure the resources for his everyday survival as consumer commodities, but as repurposed urban waste. In describing the land as "covered in cities," he frames cities as features of the natural environment and argues that dumpster diving is a form of survival based in the urban ecology of waste production and use. Townsend similarly compares the city to a "jungle" in which everyday needs are commodified. He writes:

Water becomes a commodity.... Out here, on the streets one really learns of its value.... If you were stranded in a jungle or lost in the woods, your first priorities would be shelter and water; the city is a jungle... I'd look for places with outdoor faucets on the backs of 
the building, or hidden away in back alleys where, in my embarrassment, could privately fill as many plastic gallon jugs I could carry. (2011, chapter 1)

Townsend describes the city as a "jungle" in which the resources necessary for survival are almost impossible to obtain without money. In this way, he reverses the schematic according to homeless encampments have been historically framed as "jungles," instead highlighting the commodified city as a wild and untamed landscape.

In many ways, New York City exemplifies this understanding of the city as a form of wilderness. Maxfield Harding was homeless in New York City during the 1980s, a period during which he struggled with profound anxiety. In his self-published memoir Casualty: Crazy and Homeless in New York City, he describes surviving using objects he kept from his days of recreational camping. Like Townsend, Harding frames cities and forests as two different kinds of wilderness. He writes, "I was in the wilds of New York City and I had no place to live. ... [In my backpacking days] the surrounding wilderness was natural and not man-made" (2014, chapter 1). In describing "the wilds of New York City" and "man-made" wilderness, Harding challenges popular ideologies of cities as rational and planned places. For a time, he finds shelter in an "urban wilderness shack"- a small room on the roof of an office building (2014, chapter 4). He depicts New York as a "concrete behemoth" that is utterly strange and foreign, full of fast-moving flows and noises. In contrast, he writes that the coastline outside the city was freely available and unattached to private property: "I grew up slightly north of this monstrosity of concrete and cement that was New York City and I frequented the ocean beaches that lay to the south of it and to the east. The sweet and sour air of salt water comforted me. It was something familiar that had been freely given to me" $(2014$, c. 5$)$. In emphasizing that the ocean breeze was something "freely given," Harding suggests that the city is a part of nature that has been developed and monetized to such a degree that it is no longer "freely given." 
David Wojnarowicz, a well-known artist who wrote about his youth living on the streets of New York City, similarly argues that the divide between nature and society is an illusion created by property and money systems. He distinguishes between the world that actually exists, and the illusory "Other World" that society constructs. He writes:

I sometimes get weary trying to keep up with [the Other World], minute-by-minute adapt: the world of the stoplight, the no-smoking signs, the rental world, the split-rail fencing shielding hundreds of miles of barren wilderness from the human stuff. A place where ... one is denied access to earth or space, choice or movement. The bought up world; the owned world. ... The invention of the word "nature" disassociates us from the ground we walk on. $(1991,87-88)$

In this "Other World," space is surrounded by fences, rented for money, owned, and purchased in such a way that people without money are "denied access to earth or space" as well as freedom of movement $-\mathrm{a}$ traditional articulation of capitalist value. Wojnarowicz describes the predicament of urban homelessness: with no access to money to purchase "the world," there is no space left to be in the city (Mitchell 1997). Yet at the same time as he acknowledges the ravages of urbanization and privatization of land, he asserts that the "invented" concept of nature dissociates us from the "ground we walk on," thus critiquing the ideologies that falsely separate humans from the earth.

In a later passage, Wojnarowicz expresses an affinity for remote forest spaces, and contrasts these against the culture he associates with manicured suburban lawns. As a child who was severely abused by his father, forests and lakes represented distance from the suburban social world that enabled his abuse to take place. He writes:

I grew up in a tiny version of hell called the suburbs and experienced the Universe of the Neatly Clipped Lawn. This is a place where ... violence can take place uncontested by others, as long as it doesn't stray across the boundaries and borders as formed by the deed-holder inhabiting the house on the neatly clipped lawn.... Once I discovered the universe of the forests and lakes, I went there whenever possible. (1991, 151-152). 
In this passage, Wojnarowicz associates private property—deeds, boundaries, and borders_—with the privatized cultivation of nature as a source of pleasure. He frames suburbia as a place where violence is tolerated so long as it remains within the bounds of private property. In contrasting the "universe of the neatly clipped lawn" with the "universe of the forests and trees," Wojnarowicz suggests an understanding of urban green space as a reprieve from the violence of private property. Value, in this framework, becomes more than a means of either preserving natural capital or speculating on future development, but instead can be seen as a reckoning with the here and now of survival in the capitalist city.

For many memoirists, urban green spaces also represented a crucial source for emotional wellbeing in an urban world marked by chaos and violence. Throughout his memoir, Harding describes "man-made wilderness" as contributing to his personal trauma, and "natural wilderness" as his source of healing — in essence reversing Tuan's (1972) schematic of the sacred and the profane. He writes that he enrolled in a drug treatment program outside of the city as a way to get closer to open green spaces:

The greener the view got and the fewer the buildings, the more my body lost its tension and my breathing became slower and relaxed. Soon I just became hypnotized by the land, trees and blue sky rushing by. ... I had almost forgotten what nature was like, I had been so often walking the streets of Manhattan. (Harding 2014, chapter 5)

When he later returns to the city, he describes feeling overwhelmed by anxiety:

Soon we were in the city streets and I was beginning to panic. I wanted to be in the woods. I wanted to be hiking in the wilderness with the birds making a racket when I walked beneath the trees. I wanted to come upon a small clear stream in the middle of nowhere and set up camp for the night.... I would need to go back into the wilderness again, where I knew I truly belonged. (Harding 2014, chapter 5)

While both cities and forests are "wilderness" spaces for Harding, he is explicit as to the difference between the two. The former is chaotic and terrifying_- "wilderness" in the worst 
sense of the word — while forests are places to return to and from which to depart. While his writing seems to reinforce a stark binary between city and nature, Harding flips the usual script to center the forest as a familiar domestic space, and render the city remote and dangerous. $\mathrm{He}$ simultaneously blurs this boundary by referring to New York City as a kind of wilderness of its own, marked by poverty, hardship, and the threat of displacement.

Like Wojnarowicz, many women writers described their experience of living outside as a means to gain freedom from the violence of domesticity. Homelessness among women in particular is overwhelmingly linked to domestic violence (NLCHP 2012). For many, the home becomes a site of terror and confinement, and for those without money homelessness is often the only means of escape (Meth 2003). Ressurrection Graves, in her self-published digital memoir Identity Crisis, writes about struggling in a series of abusive relationships that ultimately led to her homelessness. She similarly felt trapped inside her home and saw the outside world as full of the possibility of freedom from abuse. She writes about going to a park late at night:

I remember as a youngster how I would go outside late at night and sing to the stars. ... My response to the sun going down was excitement, for everyone to go into their respective houses, so that God and I could spend time together in the vastness of what I know he has made. ... I felt like, 'This was my house.' The entire park, neighborhood, the sky, and Jesus included. (2011, chapter 7)

In describing the park and the sky as "her house," Graves reimagines an expansive home in contrast to the confinement of the normative home. In doing so, she reassigns traditionally understood relations of value between houses and outdoor spaces - the house becomes the place devalued, replaced by the sanctuary of the stars. In emphasizing how nature can represent spiritual renewal, we do not seek to undermine the way in which remote outdoor spaces often represent exposure to racialized violence (Finney 2014), but rather to reflect the analysis of authors who describe life outside as an escape from the horrors of intimate violence. In this 
sense, nature has an affective use value, as a site of aspiration, spirituality, and liberation from an urban world marked by violent social relations.

Marie James-who wrote Orphan Girl: The Memoir of a Chicago Bag Lady with a coauthor who transcribed and edited her oral history — spent most of her childhood and adult life escaping violent intimate relationships, until she was ultimately incarcerated at the Winnebago State Mental Hospital where she was subject to institutional abuse. After attempting to kill herself multiple times, she describes a climactic moment in which she stares into the wintry forest, contemplating suicide. She writes:

There was a big plate-glass window looking out into the yard behind the building. ... The storm was over and the sun was out. The trees, those grey, ugly trees, were transformed. They were covered with ice crystal, every last trunk and branch and twig. The sun through those branches and twigs made them shine like a million prisms. The breeze touched the trees, and shimmering, shaking shards of light, moving, shifting and changing, rainbows and sparkling diamonds, flew everywhere. ... As I looked at those trees, I knew I was looking at myself. ... Then I knew I could make it. $(1998,160)$

James describes the trees appearing dead after months of a brutal and harsh winter, just as she saw herself after her countless experiences of abuse. Yet in understanding herself as a part of nature - 'I knew I was looking at myself'- and witnessing the way in which nature "transforms," she was also able to reclaim her own profound sense of the possibility of change. This realization ultimately gave her the conviction to escape the hospital. She describes running across an open field until she reached a nearby highway, with nothing but the clothes on her back.

Aside from valuing the outdoors as an escape from the violence and the confinement of domesticity, many homeless writers found emotional solace in natural phenomena amidst the brutality of anti-homeless policing. As Smith writes about living with his brother in state parks outside of Los Angeles: 
We stared out into the vast monument [of the canyon].... The one thing consistent in all of my adventures up to that point and beyond was the voice that surged deep from my belly saying, this is right; you are supposed to be here. It is easy to believe the voice when nature unfolds itself holding nothing back, arching its splendor unashamed of seduction. The time would come when the voice spoke in the face of unrelenting disappointment.... So as my story is told look for the canyon in my despair and you will understand its worth. (2011, chapter 4)

Ultimately, Smith was forced to live in more central urban parks where he was subjected to surveillance and policing, as the commuting distance to the canyon became untenable. He describes the profound sense of belonging he experienced "when nature unfolded itself," free from the confines of property, and the way in which these memories sustained him even after his homelessness became an "unrelenting disappointment." In emphasizing the "worth" of the canyon as something that sustained him through incredible hardship, he challenges the notion that the affective value of wilderness is temporary or impractical. While recreational campers are understood to share a refined appreciation of the beauty of the natural world, homeless campers who live outside by necessity are often viewed through the lens of stigma and disgust (Pendleton 2000; Rose 2014). In describing experiences of enjoying the beauty of nature, despite his material conditions, Smith defies bourgeoisie norms in which the experience of nature is viewed as elite escape, while also challenging stereotypes of homeless people as lacking aesthetic enjoyment of the natural world.

Willett also frames park dwelling as a challenge to the spatial separations people construct between society and nature. For Willett, housed society makes itself a spectator rather than participant in the natural world, observing nature through screen doors, windows, and television screens. She describes the experience of living in parks:

The sun peeping through the first clouds, beckoning our eyes open to crack the dawn. We don't see these things through glass windows, flat-screens, or wooden doors ajar. We 
don't even see these things through the mesh on a tent. We experience life up close and personal, raw, in the here and now. No walls. No barriers. (Willett 2015, chapter 2)

In framing her homelessness through the language of connection to nature, Willett challenges the stigma attached to homelessness and focuses instead on the failures and limitations of housed society. She characterizes housing in particular as an instrument through which society separates itself from nature by erecting permanent and climate-controlled structures outfitted with visual technologies. These infrastructures, in turn, make the binary between nature and society seem solid and material. For her, the value of parks is in challenging the illusion of separation.

\section{Conclusion}

In this article we advance an argument both epistemological and content-driven in nature. Homeless writers, we suggest, can be read as thinkers who have a crucial and under-represented vantage point on the American city. With shifting geographies of anti-homeless policing and green gentrification, it is crucial to acknowledge the diverse dwelling practices that take place in parks today. In particular, homeless writers describe engaging with nature as part of everyday life, rather than as a temporary retreat, and finding solace in the face of domestic violence, eviction, and police surveillance. These central themes - privacy, survival and solace — should be understood as clear manifestations of an alternative and often unseen use value of urban parks. We hope that this framing might be politically useful for activists making arguments in the face of ecological gentrification and the over-policing of urban green spaces, and for urban political ecology scholars looking to enrich current understandings of the production of value through environmental development.

While memoirs of homelessness often represent nature as a resource and solace, such representations must be placed in the broader context of extreme material deprivation, as well as 
the severe social stigma, exclusion, and spatial control that homeless people are subject to in US cities. This context is largely structured by ideas of value in urban space: where land is considered valuable either through speculation or preservation, anti-homelessness further intensifies. Rather than fetishizing or romanticizing nature, the passages we analyze here emerge from the experience of being deeply embedded in relationship with urban green spaces, and finding value outside of the capital attached to land as a commodity. While homeless authors are not immune to the influence of hegemonic discourses of nature, their writing challenges the fetishization of nature - as either sacred or profane - that is based in logics of exchange value and capitalist urbanization. Memoirs of homelessness represent parks as spaces where those most excluded by property relations can find reprieve from the hyper-surveilled and policed logics of capitalist development. From these experiences, the homeless memoirists we cite have developed new and powerful ways of understanding the value of green spaces in cities, a value that lies precisely in its distinction from the property-driven processes of urbanization.

\section{Acknowledgements}

The authors wish to thank the anonymous reviewers for their extremely helpful feedback. Additionally, we are deeply grateful to all homeless memoirists, artists, and theorists.

\section{Bibliography}

Anguelovski, I., Connolly, J. J., Garcia-Lamarca, M., Cole, H., \& Pearsall, H. 2018. New scholarly pathways on green gentrification. Progress in Human Geography, 030913251880379. http://doi.org/10.1177/0309132518803799

Beckett, K., and Herbert, S. 2009. Banished: The New Social Control in Urban America. Oxford: Oxford University Press. 
Brovsky, C. 2001. “City Park Rangers Urged.” Denver Post, December 4.

Brown, T., Bergstrp, J., \& Loomis, J. 2007. Defining, Valuing, and Providing Ecosystem Goods and Services. Natural Resources, 47, 329-376. http://doi.org/10.1533/9781845699789.5.663

Cadillac Man. 2009. Land of the Lost Souls: My Life on the Streets. New York: Bloomsbury.

Checker, M. 2011. Wiped out by the "Greenwave": Environmental gentrification and the paradoxical politics of urban sustainability. City and Society, 23(2), 210-229. http://doi.org/10.1111/j.1548-744X.2011.01063.X

Costanza, R., D’arge, R., de Groot, R., Farber, S., Grasso, M., Hannon, B., Limburg, K., Naheem, S., O'Neill, R., Paruelo, J., Raskin, R., Sutton, P., and van den Belt, M. 1997. "The Value of the World's Ecosystem Services and Natural Capital.” Nature 387: 253-260.

Cronon, W. 1996. "The Trouble with Wilderness: Or, Getting Back to the Wrong Nature." Environmental History 1(1): pp.7-28. doi:10.2307/3985059

Curran, W., \& Hamilton, T. 2013. Just Green Enough: Contesting Environmental Gentrification. Local Environment, 17(9), 1027-1042. Retrieved from https://www.planning.org/tuesdaysatapa/2013/chicago/mar.htm

Dooling, S. 2009. Ecological gentrification: A Research agenda exploring justice in the city. International Journal of Urban and Regional Research, 33(3), 621-639. http://doi.org/10.1111/j.1468-2427.2009.00860.x

Doshi, S. 2018. Greening Displacements, Displacing Green: Environmental Subjectivity, Slum Clearance, and the Embodied Political Ecologies of Dispossession in Mumbai. International Journal of Urban and Regional Research, 1-21. http://doi.org/10.1111/1468-2427.12699

Downey, D. 1995. "Corona Explores Rangers to Make City Parks Safer." The Press-Enterprise, May 13.

Eighner, L. 2013. Travels with Lizbeth: Three Years on the Road and on the Street. New York: St. Martin's Press.

Eisenman, T. S. 2016. Greening Cities in an Urbanizing Age : The Human Health Bases in the Nineteenth and Early Twenty-first Centuries. Change Over Time, 6(2), 216-246.

http://doi.org/10.1353/cot.2016.0014. 
Emmons, M. 2013. "San Jose: More Park Rangers Will Help Curb Creekside Homeless Encampments." Oakland Tribune, June 25.

Emmons, M. 2015. "San Jose's 'Jungle': Former Homeless Encampment Returns to Nature.” Oakland Tribune, July 9.

England, R. W. 2000. Natural capital and the theory of economic growth. Ecological Economics, 34(3), 425-431. http://doi.org/10.1016/S0921-8009(00)00187-7

Erickson, B. 2011. "Recreational Activism: Politics, Nature, and the Rise of Neoliberalism." Leisure Studies 30(4): 477-494. doi:10.1080/02614367.2011.594078

Finney, C. 2014. Black Faces, White Spaces: Reimagining the Relationship of African Americans to the Great Outdoors. Chapel Hill NC: University of North Carolina Press

Gandy, M. 2002. Concrete and Clay: Reworking Nature in New York City. Cambridge MA: MIT Press

Goff, L. 2016. Shantytown, USA. Somerville: Harvard University Press.

Goldfischer, E. 2018. “'Peek-A-Boo, We See You Too:' Homelessness and Visuality in New York City." Environment and Planning D: Society and Space 36(5): 831-848 doi:10.1177/0263775818768546

Goodling E, Green J and McClintock N. 2015. Uneven development of the sustainable city: Shifting capital in Portland, Oregon. Urban Geography 36(4):504-527

Gowan, T. 2010. Hobos, Hustlers, and Backsliders: Homeless in San Francisco. Minneapolis: University of Minnesota Press.

Graves, R. 2011. Identity Crisis, Identity Christ Is: A Journey to Love. Ressurrection Graves.

Harding, M. 2014. Casualty: Crazy and Homeless in New York City. Maxfield Harding.

Huber, M. 2018. Resource geographies I: Valuing nature (or not). Progress in Human Geography, 42(1), 148-159. https://doi.org/10.1177/0309132516670773

Jackson, K. 1985. Crabgrass Frontier: The suburbanization of the United States. Oxford: Oxford University Press 
Jacobs, J. 1961. The Death and Life of Great American Cities. New York: Vintage.

James, Marie (as told to Jane Hertenstein). 1998. Orphan girl: The memoir of a Chicago bag lady. Chicago, IL: Cornerstone Press.

Kay, K., \& Kenney-Lazar, M. 2017. Value in capitalist natures. Capitalism, Nature, Socialism, 28(1), 33-3. http://doi.org/10.1177/2043820617736584

Kerr, D. 2011. Derelict Paradise: Homelessness and Urban Development in Cleveland, Ohio. Amherst: University of Massachusetts Press.

Kim, G. 2011. "The Homeless Shuffle Goes On: Even Rangers Rousting Campers Along River See It's Not The Answer." The Sacramento Bee, February 15.

Kosek, J. 2006. Understories: The Political Life of Forests in Northern New Mexico. Durham: Duke University Press.

Krinsky, J. and Simonet, M. 2017. Who Cleans the Park? Chicago: University of Chicago Press

Kumar, M., \& Kumar, P. 2008. Valuation of the ecosystem services: A psycho-cultural perspective. Ecological Economics, 64(4), 808-819.

http://doi.org/10.1016/j.ecolecon.2007.05.008

Larson, S. 2013. 'Building like Moses with Jacobs in Mind:' Contemporary Planning in New York City. Philadelphia: Temple University Press

Lefebvre, H. 1991. The Production of Space. Oxford: Blackwell Publishers.

LeMieux, R. 2009. Breakfast at Sally's: One Homeless Man's Inspirational Journey. New York: Skyhorse Publishing.

Meth, P. 2003. "Rethinking the 'Domus' in Domestic Violence: Homelessness, Space and Domestic Violence in South Africa." Geoforum 34(3): 317-327. doi:10.1016/S00167185(03)00005-8

Mitchell, D. 1997. The Annihilation of Space by Law: The Roots and Implication of AntiHomeless Laws in the United States. Antipode, 29(3), 303-335.

Mitchell, D. 2003. The Right to the City: Social Justice and the Fight for Public Space. New York: Guilford Press. 
Mollins, J. 2004. "Homeless Must Leave Valley Refuge: Rangers Give Two Couples 48 Hours to Leave.” Edmonton Journal, July 1.

Moore, D, Kosek, J, Pandian, A. (eds). 2003. Race, Nature, and the Politics of Difference. Chapel Hill, NC: Duke University Press

NLCHP (National Law Center on Homelessness and Poverty). 2012. Facts on Homelessness, Housing, and Violence Against Women. Washington, DC: National Law Center on Homelessness and Poverty.

Pendleton, M. R. 2000. Leisure Crime and Cops. Journal of Leisure Research, 32(1), 111-115

Public Service Officers. 2018. City of Santa Monica Website. Accessed

from https://santamonicapd.org/Content.aspx?id=51789

Quastel, N. 2009. Political Ecologies of Gentrification. Urban Geography, 30(7), 694-725. http://doi.org/10.2747/0272-3638.30.7.694

Rice, J. L., Cohen, D. A., Long, J., \& Jurjevich, J. R. 2019. Contradictions of the ClimateFriendly City: New Perspectives on Eco-Gentrification and Housing Justice. International Journal of Urban and Regional Research. http://doi.org/10.1111/1468-2427.12740

Robbins, P. 2012. Lawn People: How Grasses, Weeds, and Chemicals Make Us Who We Are. Philadelphia: Temple University Press.

Rose, J. 2014. "Ontologies of Socioenvironmental Justice: Homelessness and the Production of Social Natures.” Journal of Leisure Research 46(3): 252. doi:10.1080/00222216.2014.11950325

Safransky, S. 2014. Greening the urban frontier: Race, property, and resettlement in Detroit. Geoforum, 56, 237-248. http://doi.org/10.1016/j.geoforum.2014.06.003

Simon, G. L., and Alagona, P. S. 2013. "Contradictions at the Confluence of Commerce, Consumption and Conservation; or, an REI Shopper Camps in the Forest, Does Anyone Notice?" Geoforum 45: 325-336. doi.org/10.1016/j.geoforum.2012.11.022

Smith, D. W. 2011. ...In a Van Down by the Ocean: A Homeless Memoir, Part 1. Frederick: America Star Books.

Smith, N. 1984. Uneven Development: Nature, Capital, and the Production of Space. Athens: University of Georgia Press 
Sparks, T. 2010. Broke Not Broken: Rights, Privacy, and Homelessness in Seattle. Urban Geography, 31(6), 842-862. http://doi.org/10.2747/0272-3638.31.6.842

Speer, J. 2016. The Right to Infrastructure: A Struggle for Sanitation in Fresno, California Homeless Encampments. Urban Geography 37(7): 1049-1069.

doi:10.1080/02723638.2016.1142150

Speer, J. 2017. "It's not like your home": Homeless Encampments, Housing Projects, and the Struggle over Domestic Space. Antipode, 49(2), 517-535. doi.org/10.1111/anti.12275

Speer, J. 2019a. "A collection of stories, poetry and theories": Homelessness, outsider memoirs, and the right to theorize. In press at GeoHumanities.

Speer, J. 2019b. "Urban Makeovers, Homeless Encampments, and the Aesthetics of

Displacement.” Social \& Cultural Geography. doi:10.1080/14649365.2018.1509115

Stuart, F. 2016. Down, Out, and Under Arrest: Policing and Everyday Life on Skid Row.

Chicago: University of Chicago Press.

Swyngedouw, E., \& Heynen, N. C. 2003. Urban political ecology, justice and the politics of scale. Antipode, 898-918. http://doi.org/10.1111/j.1467-8330.2003.00364.x

Theodore, N., Peck, J., and Brenner, N. 2011. "Neoliberal Urbanism: Cities and the Rule of Markets. In The New Blackwell Companion to the City, edited by G. Bridge and S. Watson, 1531. Malden: Wiley-Blackwell.

Townsend, D. 2011. Homeless in Houston. Douglas Townsend.

Tuan, Y. 1972. Topophilia: A Study of Environmental Perceptions, Attitudes, and Values. New York: Columbia University Press

Tuft, C. 2009. "St. Louis Park Rangers Get Tough on Homeless.” McClatchy-Tribune Business News, November 6.

Vitale, A. 2008. City of Disorder: How the Quality of Life Campaign Transformed New York Politics. New York: NYU Press.

Willett, B. 2015. How to Be a Hobo. Huntsville: Free Press Publications.

Willse, C. 2015. The Value of Homelessness: Managing Surplus Life in the United States. Minneapolis: University of Minnesota Press. 
Wojnarowicz, D. 1991. Close to the Knives: A Memoir of Disintegration. New York: Vintage Books. 